\title{
LIVER CANCER STEM CELLS
}

\section{Ranan Gülhan AKTAȘ}

Maltepe University, School of Medicine, Cancer and Stem Cell Research Center, Department of Histology \& Embryology, Istanbul, TURKEY

ORCID ID: orcid.org/0000-0002-4474-7371, e-mail: ranan.aktas@ maltepe.edu.tr

Cite this article as:

Aktaş R.G. 2019. Liver Cancer Stem Cells. Trakya Univ J Nat Sci, 20(Special Issue): S55-S61, DOI: 10.23902/trkjnat.486558

Received: 22 November 2018, Accepted: 22 January 2019, Published: 1 February 2019

\begin{abstract}
Recent studies have shown that many tumour are containing small population of stem cell-like cells, in other words, cancer stem cells. The rapid development of the cancer stem cell field has allowed the scientists and the clinicians to focus on another challenge, which targets cancer stem cells for new therapeutic strategies. Studies showed that novel therapeutic approaches on the selective targeting of cancer stem cells might be extremely successful for prevention of invasion, metastasis, and the relapses of tumors.

Liver cancer is the $5^{\text {th }}$ most common cancer type. It has also been reported as the $3^{\text {rd }}$ most common cause of cancer related death. Recently, progression of hepatocellular carcinoma is thought to be driven by cancer stem cells. There are tremendous efforts to clarify the features of liver cancer stem cells, to identify them within other tumor cells, and finally to develop the new therapeutic models that target those cells. This review summarizes the features of liver cancer stem cells, and its importance for therapeutic approaches.
\end{abstract}

Key words: Liver, cancer, stem cell, hepatocellular carcinoma.

Özet: Son yıllarda yapılan araştırmalar, birçok tümörün az miktarda da olsa kök hücre benzeri özellik içeren hücreler, bir diğer değişle kanser kök hücreleri içerdiğini göstermektedir. Kanser kök hücreleri ile ilgili araştırmalar ve buna bağlı ortaya çıkan hızlı gelişmeler, gerek hekimlerin gerekse bilim insanlarının diğer bir konu olan yeni tedavi stratejileri için kanser kök hücrelerinin kullanımı üzerinde yoğunlaşmalarına olanak tanımıştır. Bu alandaki araştırmaların sonuçları, kanserin invazyonu, metastazı ve tekrarlamasını önlemede kanser kök hücrelerini hedef alan tedavi yaklaşımlarının son derece başarılı olabileceğini ortaya koymaktadır.

Karaciğer kanseri, tüm kanser türleri arasında 5. sırada yer almaktadır. Kansere bağlı ölümlerde ise 3. sırada yer almaktadır. Hepatosellüler karsinomanın ilerlemesinde kanser kök hücrelerinin çok önemli rolü olduğu gösterilmiş̧ir. Karaciğer kanser kök hücrelerinin tanımlanması, diğer tümör hücrelerinden ayrılabilmesi ve bu hücreleri hedef alan yeni tedavi şekillerinin geliştirilebilmesi konularında çok önemli gelişmeler vardır. Bu derlemede, son yıllarda bu alanlarda yapılan çalışmalar esas alınarak karaciğer kanser kök hücrelerinin özellikleri ve bu hücreleri hedef alan yeni tedavi yaklaşımları özetlenmektedir.

\section{Introduction}

Cancer stem cells (CSCs), a small population of stem cell-like cells in tumour- (are extremely resistant to chemotherapy and radiation, and considered as responsible for invasion and metastasis of the cancer. Translational studies present more clues related to the responsibility of these cells for the relapses of tumors (Alison 2005, Kitisin et al. 2007).

Liver cancer is the $5^{\text {th }}$ most common cancer type all around the world, and was reported as the $3^{\text {rd }}$ common deadly cancer. According to the data base of Turkish Health Ministry, the incidence of liver cancer was 1.5 to 4.4/100.000 in Turkey between the years 2010 and 2014 .

There are tremendous efforts to clarify the features of liver CSCs, to identify these cells within other tumor cells, and finally to develop new therapeutic models targeting these cells. Liver cancer stem cells (LCSCs) have been reported in multiple subtypes of hepatocellular carcinoma. They are considered as the master regulators of hepatocellular carcinoma initiation, tumor metastasis and progression. The stem cells and progenitor cells are elevated in chronic liver diseases (Roskams 2006, Kitisin et al. 2007).

This review summarizes the recent findings related to LCSCs, and developments about therapeutic approaches targeting these cells.

The origin of LCSC is still controversial. They are proposed to have two origins, one endogenous and the other exogenous. When LCSCs are intrahepatic, they are considered to have the endogenous origin. Intrahepatic stem cells are mainly localized within the canals of Hering and also seen around the interlobular bile ducts. They turn to hepatic progenitor cells which have short term proliferative capacity. 
There are also extrahepatic stem cells of exogenous origin which are derived from bone marrow and/or peripheral blood cells. These exogenous cells have long term proliferation capacity (Alison 2005). Castelli et al. (2017) reported that the mutation of cancer cells causes formation of new LCSCs.

\section{How to identify LCSCs?}

\section{A. Functional Properties of LCSCs}

There are assays that are routinely used to discriminate CSCs from non-stem cells (non-CSCs) on the basis of their functional properties, such as aldehyde dehydrogenase (ALDH) activity, side population analysis, colony formation, sphere formation, and therapy resistance assays (Islam et al. 2015, Aktas \& Tok, 2014, 2015, Xiang et al. 2016, Tok \& Aktas, 2017).

ALDH is the main enzymatic system responsible for the clearance of acetaldehyde from the hepatocytes in the liver tissue. It is involved in retinoic acid signaling pathway known as differentiation of the hepatocytes (Tomita et al. 2017). ALDH1-expressing cells may serve as a useful differentiation biological marker for hepatocellular carcinoma rather than as a CSC marker. These cells show features of differentiated cells that look like mature hepatocytes but not of CSCs. Taken together, these findings suggest that increased ALDH1 expression is associated with a factor indicative of a welldifferentiated morphology and favorable prognosis in hepatocellular carcinoma (Sun et al. 2016).

The presence of active transmembrane ABC transporter family members, such as multidrug resistance transporter 1 (MDR1) and ABCG2, can facilitate the efflux of DNA-binding dyes such as Hoechst 33342 in cells with (cancer) stem cell activity known as the side population. Side population cells possess high proliferation potential, tumorigenicity, and anti-apoptotic properties.

\section{B. Cell surface markers}

LCSCs can be identified by using cell sorting methods like flow-cytometry and magnetic-activated cell sorting (MACS) separate CSCs from non-CSCs on the basis of different cell surface and intracellular molecules. The most common cell-surface markers used to detect the LCSCs were detailed below (Chiba et al. 2009, Yamashita et al. 2013, Islam et al. 2015).

\section{$\underline{C D 133}$}

Many studies have been performed about the expression of CD133 in different types of cancers, including hepatocellular carcinoma (Sun et al. 2016). In human hepatocellular carcinoma cells and cell lines, specifically $\mathrm{CD}_{133^{+}}$cells, not $\mathrm{CD} 133^{-}$cells, have the ability to self-renewal, create differentiated progenies and form tumors (Ma 2007). They have characteristics similar to those of progenitor cells including the expression of stemness genes. This coincided with the expression of genes associated with stem/progenitor status, such as bcatenin, NOTCH, BMI and OCT3/4. CD $133^{+}$cells possess a greater ability to form tumors in vivo. When compared to CD133- cells, CD133+ cells isolated from the cell lines showed higher expression of CD44 and CD34, but both CD133 subpopulations displayed similar expression for CD29, CD49f (integrin a6), CD90 and CD117 (Ma 2007).

Increased CD133 levels are correlated with increased tumor grade, advanced disease stage, shorter overall survival, and higher recurrence rates. Regulation of cell membrane topology is related to existence of CD133.

\section{$\underline{\operatorname{EpCAM}(C D 326)}$}

EpCAM is a cell adhesion molecule. In addition to epithelial cells, stem cells also express EpCam (Trzpis et al. 2007). It has crucial roles for cell migration and signaling. $\mathrm{EpCAM}^{+}$cells were correlated with tumor progression and invasiveness. It can mediate cell to cell contact, transmit the signals from the plasma membrane to the nucleus in order to regulate gene transcription (Munz et al. 2009). Expression of EpCAM is associated with a stem cell phenotype and regenerative capacity of the cells. DeBooer et al. (1999) showed that EpCAM expression is only found in regenerating cells, like hepatobiliary stem cells and progenitor cells. EpCAM ${ }^{+}$and Alpha feto protein $(+)$cells have features of hepatic stem/progenitor cells. EpCAM was also identified as a direct transcriptional target of $\mathrm{Wnt} / \beta$ catenin signaling pathway in hepatocellular carcinoma (Yamashita et al. 2009). Wnt/ $\beta$-catenin signaling pathway has a crucial role in induction of C-myc, Nanog, Klf4, Sox2 and Oct4 (Zhang et al. 2012, Tetreault 2016, Xu et al. 2016, Zhan et al. 2017)

$\underline{\text { Oct4 }}$

Oct4 hepatocellular carcinoma cells have dysfunctional TGF- $\beta$ signaling. This stem cell marker is responsible for the regulation of stem cell identity and cell fate. They are likely cancer progenitor cells that have the potential to give rise to hepatocellular carcinoma (Yuan et al. 2010, Oishi et al. 2014).

Accumulated evidence from various cancer types strongly support the hypothesis that hypoxia sustains the self-renewal characteristics of a portion of cancer cells in hypoxic niches mainly due to the upregulation of Oct4, NANOG, SOX2, Klf4, and c-myc (Mathieu et al. 2011, Muz et al. 2014).

\section{CD44}

CD44 is important for cell adhesion, migration, cellcell interactions and cell signaling. Mima et al. (2012) showed that the patients with hepatocellular carcinoma were characterized with poor prognosis when $\mathrm{CD} 44^{+}$cells regulated the TGF- $\beta$-mediated mesenchymal phenotype. Overexpression of CD44s promoted tumor invasiveness and increased the expression of vimentin, a mesenchymal marker, in hepatocellular carcinoma cells. 


\section{$\underline{C D 90}$}

Cancer cell behavior related to cell to cell adhesion and signal transduction is affected by the existence of CD90. The higher $\mathrm{CD}^{+} 0^{+}$cell proliferation ability and higher tumor promoting capacity observed in vitro correlate with the in vivo data. $\mathrm{CD} 90^{+}$molecule was found to be increased during the progression of hepatocellular carcinoma (Sukowati et al. 2013). It has also been reported that $\mathrm{CD} 90^{+}$cells enhanced the motility of $\mathrm{EpCAM}^{+}$cells when co-cultured in vitro through the activation of transforming growth factor beta (TGF- $\beta$ ) signaling, whereas imatinib mesylate suppressed TGFB1 expression in $\mathrm{CD}^{+} 0^{+}$cells as well as $\mathrm{CD}^{+} 0^{+}$cell-induced motility of $\mathrm{EpCAM}^{+}$cells (Yamashita et al. 2013).

\section{$\underline{C D 24}$}

Qui et al. (2011) demonstrated that hepatocyte progenitor cells possess CD24. It has also been stated that $\mathrm{CD} 24^{+}$liver tumor-initiating cells drive self-renewal and tumor initiation through STAT3-mediated NANOG regulation (Lee et al. 2011-a and b).

\section{$\beta$-catenin}

This is another important marker for cell adhesion and effects the behavior of stem cell in terms of the cell behavior related to epithelial-mesenchymal transition.

\section{$\underline{C D 13}$}

CD13 is involved in regulation of peptides and lipid turnover, and reduction of DNA damage induced by reactive oxygen species (ROS). $\mathrm{CD}^{+} 3^{+}$cells predominated in the $G_{0}$ phase of the cell cycle and typically formed cellular clusters in cancer foci. Mechanistically, CD13 reduced ROS-induced DNA damage after genotoxic chemo/radiation stress and protected cells from apoptosis (Haraguchi et al. 2010).

\section{$\underline{\mathrm{O} 6} 6$}

Yang et al. (2008 and 2014) showed that Wnt/betacatenin signaling contributes to activation of normal and tumorigenic liver progenitor cells and $\mathrm{OV}^{+}$tumorinitiating cells contribute to tumor progression and invasion in human hepatocellular carcinoma.

\section{Relationship Between LCSCs and Signaling Pathways}

The following signaling pathways are considered as stem cell activators. They expedite tumorigenesis.

\section{i. Wht/ $\beta$-catenin Signaling Pathway}

Wnt pathway is crucial for specification of cellular fates and movements. This pathway is essential for cell development, growth, survival, regeneration and selfrenewal. Disruption of this pathway may cause cancer. One third of liver cancer cases contain mutational/nonmutational changes in this pathway (Ishizaki et al. 2004).

The pathway diversifies into two branches as $\beta$ catenin dependent and non-dependent ways. The $\beta$ catenin dependent pathway has critical roles during embryogenesis, while the independent branch is important for adult tissue regeneration (Bowen et al. 2008). Yang et al. (2008) demonstrated that the fraction of tumor cells expressing OV6 is enriched after Wnt pathway activation, whereas inhibition of $\beta$-catenin signaling leads to a decrease in the proportion of $\mathrm{OV6}^{+}$ cells.

\section{ii. SALLA Signaling Pathway}

SALL4 is considered as an oncofetal gene. It is expressed at high levels in fetal liver progenitor cells. It is important for the maintenance of stemness of embryonic stem cells. SALL4 may be a prognostic marker of liver cancer and an indicator of stem cells, playing roles in 5FU resistance and growth of cells, and tumors with suppressed SALL4 results in differentiation and delayed tumor growth. It has been recognized as a marker for poor prognosis (Sun et al. 2016).

\section{iii. TGF- $\beta$ Signaling Pathway}

TGF- $\beta$ is unique in that in normal cells it acts to maintain the epithelial nature of cells whereas in transformed cells, it is mostly oncogenic in its activity. TGF- $\beta$ family plays a vital role in proliferation and cellular differentiation in both stem cells and cancer cells. It inhibits cell proliferation and promotes tumor cell invasion by inducing epithelial mesenchymal transition (EMT). Yuan et al. (2010) showed the relationship between Oct 4 and TGF- $\beta$ family. Additionally, Fan et al. (2014) demonstrated that tumor associated macrophages sustain $\mathrm{EpCAM}^{+}$LCSCs through TGF $\beta 1$ induction of EMT.

\section{iv. Notch Signaling Pathway}

This signaling pathway is crucial during liver embryogenesis, bile duct formation, and angiogenesis. $\mathrm{CD}_{133^{+}}$cells express more Notch. Notch 1 functions as a tumor suppressor. However, Notch 3 is highly expressed in hepatocellular carcinoma.

\section{v. Sonic Hedgehog Signaling Pathway}

Mutations and/or aberrant activation of Sonic Hedgehog Signaling Pathway may cause cancers. It controls cell fate specification and pattern formation during embryogenesis. Sonic is the predominant isoform in the liver and up to $60 \%$ of human hepatocellular carcinoma express Sonic. Activation of Hedgehog Pathway is critically related to LCSCs and EMT (Villavicenci et al. 2000, Lum et al. 2004).

\section{Epigenetic Regulation of LCSCs and Progenitor Cells}

Although various genes have been identified as stem cell related, the control of stem cells is likely to arise from an integrated expression pattern of multiple genes involved in proliferation and differentiation rather than decimal gene expression (Koike et al. 2012).

\section{Anticancer Therapies Targeting Liver Cancer Stem Cells}

LCSCs clearly have complex pathogenesis. Targeting the single pathway or a molecule related to LCSCs may 
have limited benefits. Combinations of therapies may be needed to eradicate the cancer. Many new therapeutic strategies targeting LCSCs at various stages of differentiation or targeting microenvironment have been attempted. The followings are the recent strategies to eradicate the cancer that target the LCSCs.

\section{i. Blockage of LCSCs Signaling Pathways}

Attribution of these signaling pathways are needed to eradicate these resistant cells. Additionally, chemical intervention or downregulation of the signaling pathways may increase the sensitivity of LCSCs to treatment. The followings are the main results of several groups of scientists who demonstrated the importance of the therapies that target LCSCs;

a- Inhibition of $\mathrm{Wnt} / \beta$-catenin Signaling Pathway causes decreased proliferation and increased apoptosis (Zeng K et al. 2007; Gedaly et al. 2014).

b- Suppression of Sonic Hedgehog Patwhway in hepatocellular carcinoma decreases cell proliferation, induces apoptosis and the cells are more chemosensitized to 5-fluorouracil (Wang et al. 2008).

c- Morell \& Strazzabosco (2014) presents evidence related to targeting Notch signaling as a new therapeutic option.

\section{ii. Differentiation of LCSCS}

There are preliminary evidences of induced differentiation to effectively deplete tumorigenesis by the tumor initiating cells (Lin 2014). You et al. (2014) showed that knockdown of BC047440 induces differentiation of hepatocellular CSCs and should be considered as an alternative treatment. Hepatocyte nuclear factor- $4 \alpha$ induces differentiation of LCSCs, which may help to loose of the property of self-renewal (Yin et al. 2009). Interferon alpha accelerates hepatocytic and biliary differentiation of oval cells (Lim et al. 2006). Oncostatin M, an interleukin 6 related cytokine, induce differentiation of hepatoblasts into hepatocytes.

\section{iii. Targeting EpCAM}

Oncostatin $M$ may also be used to induce differentiation and active cell division of dormant EpCAM $^{+}$LCSCs.

\section{iv. Detection and Isolation of LCSCs}

These therapeutic approaches are based on identification of cell surface molecules on LCSCs and then isolation of the cells (Moghbeli et al. 2014). Bach et al. (2013) demonstrated the elimination of CD133 ${ }^{+}$cells. Waldron et al. (2014) presented that a bispecific EpCAM/CD133-targeted toxin is effective against carcinoma. Song et al. (2013) reported the way to capture the CSCs during circulation. A recent discovery by Lee $e t$ al. (2011-b) showed that lupeol, a phytochemical present in fruits and vegetables, could target CD133+ liver CSCs by inhibiting their self-renewal and tumorigenic capacity. v. Microenvironment is crucial for the functions of LCSCS.

Modification of the microenvironment is extremely important for determination of the LCSCs fate. The hepatic microenvironment is drastically altered in chronic liver diseases with the expansion of hepatic progenitor cells. There are approaches that target extracellular matrix, immune cells, the cells in stroma and also cytokine network to eliminate CSCs in the tumor niche.

Activation of stromal cells may induce various signaling pathways, including cytokines such as Wnt, FGF, PDGF, VEGF and TGF- $\beta$, and promote the development of LCSCs (Yamashita \& Wang 2013). Lin et al. (2009) was successful in their experimental study by using a STAT3 inhibitor - NSC 74859- to disrupt TGFbeta signaling in cancer.

Infiltrating lymphocytes in the microenvironment might cause inflammation with the release of free radicals, cytokines, and chemokines, resulting in DNA damage, cell proliferation, and migration (Budhu et al. 2006, Hussain et al. 2007).

Our studies also demonstrated the relationship between LCSCs, EMT and Type I collagen in the microenvironment (Isan et al. 2018).

\section{vi. Inhibition of Epithelial Mesenchymal Transition}

The association between CSCs and EMT has recently been established (Mani et al. 2008, Chang et al. 2015). Sun et al. (2014) demonstrated that induction of EMT correlated with the enhancement of CSC marker CD133. Mitra et al. (2015) identified the existence of Vimentin on the surface of liver CSCs and utilized this in a separation technique to enrich EMT-positive CSCs directly from primary tumor cells. It has also been shown that CD44 protein levels were enhanced by TGF- $\beta 1$ treatment and that synergistic interactions between CD44 and TGF- $\beta 1$ induced EMT and CSC phenotypes through Akt/GSK-3 $/ \beta$-catenin signaling axis in HCC (Park et al. 2016).

The link between CSC and EMT markers has been explored in HCC patient cohort (Zhou et al. 2015). Liu et al. (2015) demonstrated that shRNA mediated CD44 or CD133 knockdown reversed the EMT phenotype. Similarly, it has been reported in another study that CD44 inhibited the metastasis of hepatocellular carcinoma by reversing EMT (Gao et al. 2015).

Taken together, experimental and clinical studies support the hypothesis that CSCs mediate metastasis by maintaining plasticity to transition between epithelial or mesenchymal states. One potential approach is to use monoclonal antibodies, like CD44 or CD133, to target the CSC cell surface antigens that regulate EMT. Targeting of the TGF- $\beta$ and/or BMI- 1 that are involved in EMT might be another promising approach to eradicate these cells. 


\section{Future Directions}

Liver cancer (hepatocellular carcinoma) is the $5^{\text {th }}$ most common cancer type. It is the $3^{\text {rd }}$ deadly cancer all around the world. From the clinical view, combined therapies, that also target the liver cancer stem cells, might play the key role for prevention of invasion, metastasis, and also the recurrence of the hepatocellular carcinoma. Recent studies suggest that the targeting of single molecules or

\section{References}

1. Aktas, R.G. \& Tok, O.E. 2014. Expression Patterns of FActin and Nanog, an embryonic stem cell marker, in monolayer and spheroid culture of human liver carcinoma cell line. The American Society for Cell Biology and International Federation of Cell Biology Meeting, Mol Biol Cell, Abstracts, 18-20, December, San Diego, California.

2. Aktas, R.G. \& Tok, O.E. 2015. Localization of embryonic stem cell markers (Oct4, Nanog, Sox2, SSEA-4, TRA-1) in tumour spheroids of hepatocellular carcinoma cell line after confluency in long-term cell cultures. $2^{\text {nd }}$ International Congress on Stem Cell and Cellular Therapies, 15-18, October, Antalya, Turkey.

3. Alison, M.R. 2005. Liver stem cells: implications for hepatocarcinogenesis. Stem Cell Reviews, 1(3): 253-60.

4. Bach, P., Abel, T., Hoffmann, C., Gal, Z., Braun, G., Voelker, I., Ball, C.R., Johnston, I.C., Lauer, U.M., HeroldMende, C., Mühle-bach, M.D., Glimm, H. \& Buchholz, C.J. 2013. Specific elimination of CD133+ tumor cells with targeted oncolytic measles virus. Cancer Research, 73(2): 865-874.

5. De Boer, C.J., van Krieken, J.H., Janssen-van Rhijn, C.M. \& Litvinov, S.V. Expression of Ep-CAM in normal, regenerating, metaplastic, and neoplastic liver. The Journal of Pathology, 188: 201-206.

6. Bowen K.N. \& Monga S.P.S. 2008. Wnt/b-catenin signaling in hepatic organogenesis. Organogenesis, 4(2): 92-99.

7. Budhu, A. 2006. Prediction of venous metastases, recurrence, and prognosis in hepatocellular carcinoma based on a unique immune response signature of the liver microenvironment. Cancer Cell, 10(2): 99-111.

8. Castelli, G., Pelosi, E. \& Testa U. 2017. Liver cancer: Molecular characterization, clonal evolution and cancer stem cells. Cancers (Basel), 9(9): 127-73.

9. Chang, Y.W., Su Y.J. \& Hsiao, M. 2015. Diverse targets of $\beta$-catenin during the epithelial-mesenchymal transition define cancer stem cells and predict disease relapse. Cancer Research. 75(16): 3398-3410.

10. Chiba, T., Kamiya, A., Yokosuka, O. \& Iwam, A. 2009. Cancer stem cells in hepatocellular carcinoma: Recent progress and perspective. Cancer Letters, 286: 145-153.

11. Fan, Q. M., Jing, Y. Y., Yu, G. F., Kou, X. R., Ye, F. \& Gao, L. 2014. Tumor-associated macrophages promote cancer stem cell-like properties via transforming growth factor-beta1-induced epithelial-mesenchymal transition in hepatocellular carcinoma. Cancer Letters, 352, 160-168.

12. Gao, Y., Ruan, B., Liu, W., Wang, J., Yang, X., Zhang, Z., Li,X., Duan, J., Zhang, F. \& Ding, R. 2015. Knockdown of pathways might have limited benefit for treatment of cancer (Yamashita \& Wang 2013). In addition to the direct control of liver CSCs, many other factors are needed for CSC maintenance including angiogenesis, vasculogenesis, invasion and migration, hypoxia, immune evasion, multiple drug resistance, and radioresistance. The promising results of the recent studies give hope to clinicians and the patients for better therapies.

CD44 inhibits the invasion and metastasis of hepatocellular carcinoma both in vitro and in vivo by reversing epithelialmesenchymal transition. Oncotarget, 6: 7828-7837.

13. Gedaly, R., Galuppo, R., Daily, M.F., Shah, M., Maynard, E., Chen, C., Zhang, X., Esser, K.A., Cohen, D.A., Evers, B.M., Jiang, J. \& Spear, B.T. 2014. Targeting the Wnt/ $\beta$ catenin signaling pathway in liver cancer stem cells and hepatocellular carcinoma cell lines with FH535. PLoS One, 9(6): e99272.

14. Haraguchi, N., Ishii, H., Mimori, K., Tanaka, F., Ohkuma, M., Kim, H.M., Akita, H., Takiuchi, D., Hatano, H., Nagano, H., Barnard, G.F., Doki, Y. \& Mori, M. 2010. CD13 is a therapeutic target in human liver cancer stem cells. The Journal of Clinical Investigation, 120(9): 33263339.

15. Hussain, S.P., Schwank, J., Staib, F., Wang, X.W. \& Harris, C.C. 2007. TP53 mutations and hepatocellular carcinoma: insights into the etiology and pathogenesis of liver cancer. Oncogene, 26(15): 2166-2176.

16. Isan, H., Akbulut, Z., Cakil, Y.D. \& Aktas R.G. 2018. The Relationship Between Cancer Stem Cells, Epithelial Mesenchymal Transition and Microenvironment Containing Type I Collagen During Proliferation and Differentiation Stages of Hepatocellular Carcinoma Cells. $10^{\text {th }}$ International Heinrich F. C. Behr-Symposium on Stem Cells and Cancer. Abstract Book, 86.

17. Ishimoto, T. 2011. CD44 variant regulates redox status in cancer cells by stabilizing the xCT subunit of system xc(-) and thereby promotes tumor growth. Cancer Cell, 19(3): 387-400.

18. Ishizaki, Y., Ikeda, S., Fujimori, M., Shimizu, Y., Kurihara, T., Itamoto, T., Kikuchi, A., Okajima, M. \& Asahara, T. 2004. Immunohistochemical analysis and mutational analyses of beta-catenin, Axin family and APC genes in hepatocellular carcinomas. International Journal of Oncology, 24: 1077-1083.

19. Islam, F., Gopalan, V., Smith, R.A. \& Lam, A.K. 2015. Translational potential of cancer stem cells: A review of the detection of cancer stem cells and their roles in cancer recurrence and cancer treatment. Experimental Cell Research, 335(1): 135-47.

20. Kitisin, K., Shetty, K., Mishra, L. \& Johnson, L.B. 2007. Hepatocellular stem cells. Cancer Biomark, 3: 251-262.

21. Koike, H. \& Taniguchi, H. 2012. Characteristics of hepatic stem/progenitor cells in the fetal and adult liver. Journal of Hepato-Biliary-Pancreatic Sciences, 19(6): 587-593.

22. Lee, T.K., Castilho, A., Cheung, V.C., Tang, K.H., Ma, S. \& Ng, I.O. 2011 (a). CD24(+) liver tumor-initiating cells 
drive self-renewal and tumor initiation through STAT3mediated NANOG regulation. Cell Stem Cell, 9(1): 50-63.

23. Lee, T.K., Castilho, A., Cheung, V.C., Tang, K.H., Ma, S. \& Ng, I.O. 2011 (b). Lupeol targets liver tumor-initiating cells through phosphatase and tensin homolog modulation. Hepatology, 53: 160-170.

24. Lim, R., Knight, B., Patel, K., McHutchison, J.G., Yeoh, G.C. \& Olynyk, J.K. 2006. Antiproliferative effects of interferon alpha on hepatic progenitor cells in vitro and in vivo. Hepatology, 43(5): 1074-83.

25. Lin, C.Y. 2014. Differentiation Therapy with Cancer Stem Cells. Journal of Stem Cell Research \& Therapy, 4(1): e117.

26. Lin, L., Amin, R., Gallicano, G.I., Glasgow, E., Jogunoori, W., Jessup, J.M., Zasloff, M., Marshall, J.L., Shetty, K., Johnson, L., Mishra, L. \& He, A.R. 2009. The STAT3 inhibitor NSC 74859 is effective in hepato-cellular cancers with disrupted TGF-beta signaling, Oncogene, 28: 961972.

27. Liu, Y.M., Li, X.F., Liu, H. \& Wu, X.L. 2015. Ultrasoundtargeted microbubble destruction-mediated downregulation of CD133 inhibits epithelial-mesenchymal transition, stemness and migratory ability of liver cancer stem cells. Oncology Reports, 34: 2977-2986.

28. Lum, L. \& Beachy, P.A. 2004. The Hedgehog response network: sensors, switches, and routers. Science, 304: 1755-1759.

29. Ma, S. 2007. Identification and characterization of tumorigenic liver cancer stem/progenitor cells. Gastroenterology, 132: 2542-2556.

30. Mani, S.A., Guo, W. \& Liao, M.J. 2008. The epithelialmesenchymal transition generates cells with properties of stem cells. Cell, 133(4): 704-715.

31. Mima, K., Okabe, H., Ishimoto, T., Hayashi, H., Nakagawa, S., Kuroki, H., Watanabe, M., Beppu, T., Tamada, M., Nagano, O., Saya, H. \& Baba, H. 2012. CD44s regulates the TGF-beta-mediated mesenchymal phenotype and is associated with poor prognosis in patients with hepatocellular carcinoma. Cancer Research, 72(13): 3414-3423.

32. Mitra, A., Satelli, A., Xia, X., Cutrera, J., Mishra, L. \& Li, S. 2015. Cell-surface Vimentin: a mislocalized protein for isolating csVimentin(+) CD133(-) novel stem-like hepatocellular carcinoma cells expressing EMT markers. International Journal of Cancer, 137: 491-496.

33. Mathieu, J., Zhang, Z., Zhou, W., Wang, A. J., Heddleston, J. M., Pinna, C. M., Hubaud, A., Stadler, B., Choi, M., Bar, M., Tewari, M., Liu, A., Vessella, R., Rostomily, R., Born, D., Horwitz, M., Ware, C., Blau, C.A., Cleary, M.A., Rich, J.N. \& Ruohola-Baker, H. (2011). HIF induces human embryonic stem cell markers in cancer cells. Cancer Research, 71(13): 4640-4652.

34. Moghbeli, M., Moghbeli, F., Forghanifard, M.M. \& Abbaszadegan, M.R. 2014. Cancer stem cell detection and isolation. Medical Oncology, 31(9): 69.

35. Morell, C.M. \& Strazzabosco, M. 2014. Notch signaling and new therapeutic options in liver disease. Journal of Hepatology, 60(4): 885-890.
36. Muz, B., de la Puente, P., Azab, F., Luderer, M., and Azab, A. K. 2014. Hypoxia promotes stem cell-like phenotype in multiple myeloma cells. Blood Cancer Journal, 4: e262.

37. Munz, M., Baeuerle, P.A. \& Gires, O. 2009. The emerging role of EpCAM in cancer and stem cell signaling. Cancer Research, 69(14): 5627-5629.

38. Oishi, N., Yamashita, T. \& Kaneko, S. 2012. Transcriptomic profiling reveals hepatic stem-like gene signatures and interplay of $\mathrm{miR}-200 \mathrm{c}$ and epithelialmesenchymal transition in intrahepatic cholangiocarcinoma. Hepatology, 56(5): 1792-1803.

39. Qiu, Q., Hernandez, J.C., Dean, A.M., Rao, P.H. \& Darlington G.J. 2011. CD24-positive cells from normal adult mouse liver are hepatocyte progenitor cells. Stem Cells and Development, 20(12): 2177-2188.

40. Park, N.R., Cha, J.H., Jang, J.W., Bae, S.H., Jang, B., Kim, J.H., Hur, W., Choi, J.Y., Yoon, S.K. 2016. Synergistic effects of CD44 and TGF-betal through AKT/GSK3beta/beta-catenin signaling during epithelialmesenchymal transition in liver cancer cells. Biochemical and Biophysical Research Communications, 477: 568-574.

41. Roskams, T. 2006. Liver stem cells and their implication in hepatocellular and cholangiocarcinoma. Oncogene, 25(27): 3818-3822.

42. Sukowati, C.H.C., Anfuso, B., Torre, G., Francalanci, P., Crocè, L.S. \& Tiribelli, C. 2013. The Expression of CD90/Thy-1 in Hepatocellular Carcinoma: An In Vivo and In Vitro Study. PlosOne, 8(10): 1-11.

43. Song, Y., Zhu, Z., An, Y., Zhang, W., Zhang, H., Liu, D., Yu, C., Duan, W. \& Yang, C.J. 2013. Selection of DNA aptamers against epithelial cell adhesion molecule for cancer cell imaging and circulating tumor cell capture. Analytical Chemistry, 85(8): 4141-4149.

44. Sun, J.H., Luo, Q., Liu, L.L. \& Song, G.B. 2016. Liver cancer stem cell markers: Progression and therapeutic implications. World Journal of Gastroenterology, 22(13): 3547-3557.

45. Sun, Y., Song, G.D., Sun, N., Chen, J.Q. \& Yang, S.S. 2014. Slug overexpression induces stemness and promotes hepatocellular carcinoma cell invasion and metastasis. Oncology Letters, 7: 1936-1940.

46. Tanaka, K., Tomita H., Hisamatsu, K., Nakashima, T., Hatano, Y. \& Sasaki, Y. 2015. ALDH1 A1- overexpressing cells are differentiated cells but not cancer stem or progenitor cells in human hepatocellular carcinoma. Oncotarget, 6(28): 24722-24732.

47. Tetreault M., Weinblatt, D., Shaverdashvili, K., Yang, Y. \& Katz, J.P. 2016. KLF4 transcriptionally activates noncanonical WNT5A to control epithelial stratification. Scientific Reports, 6: 1-9.

48. Tok, O.E. \& Aktas, R.G. 2017. Serial passaging effects the carcinogenicity, stemness and spheroid formation of HEPG2 cells, a hepatocellular carcinoma cell line. Abstract Book, 401-402, $13^{\text {th }}$ Multinational Congress on Microscopy, September 24-29, Rovinj, Croatia.

49. Tomita, H., Kanayama, T., Niwa, A., Noguchi, K., Ishida, K., Niwa, M. \& Hara, A. 2017. Cancer Stem Cells and Aldehyde Dehydrogenase 1 in Liver Cancers. Updates in Liver Cancer. Chapter 3. 1-20 
50. Trzpis, M., McLaughlin, P.M., de Leij, L.M. \& Harmsen, M.C. 2007. Epithelial cell adhesion molecule: more than a carcinoma marker and adhesion molecule. The American Journal of Pathology, 171(2): 386-395.

51. Villavicencio, E.H., Walterhouse, D.O. \& Iannaccone, P.M. 2000. The sonic hedgehog-patched-gli pathway in human development and disease. American Journal of Human Genetics, 67(5): 1047-1054.

52. Waldron, N.N., Barsky, S.H., Dougherty, P.R. \& Vallera, D.A. 2014. A bispecific EpCAM/CD133-targeted toxin is effective against carcinoma. Targeted Oncology, 9(3): 239249.

53. Wang, H.Y. 2012. OV6(+) tumor-initiating cells contribute to tumor progression and invasion in human hepatocellular carcinoma. Journal of Hepatology, 57(3): 613-620.

54. Wang, Q., Huang, S., Yang, L., Zhao, L., Yin, Y., Liu, Z., Chen, Z., \& Zhang, H. 2008. Down-regulation of Sonic hedgehog signaling pathway activity is involved in 5fluorouracil-induced apoptosis and motility inhibition in Hep3B cells. Acta biochimica et biophysica Sinica (Shanghai), 40(9): 819-829.

55. Wang, R., Sun, Q., Wang, P., Liu, M., Xiong, S., Luo, J., Huang, H., Du, Q., Geller, D.A. \& Cheng B. 2016. Notch and $\mathrm{Wnt} / \beta$-catenin signaling pathway play important roles in activating liver cancer stem cells. Oncotarget, 7(5): $5754-5768$.

56. Yamashita, T, Honda, M., Nakamoto, Y., Baba, M., Nio, K., Har, Y., Zeng, S.S., Hayashi, T., Kondo, M., Takatori, H., Yamashita, T., Mizukoshi, E., Ikeda, H., Zen, Y., Takamura, H., Wang, X.W. \& Kaneko, S. 2013. Discrete nature of EpCAM+ and CD90+ cancer stem cells in human hepatocellular carcinoma. Hepatology, 57(4): 1484-97.

57. Yamashita, T., Ji J., Budhu, A., Forgues, M., Yang, W., Wang, H.Y., Jia, H., Ye, Q., Qin, L.X., Wauthier, E., Reid, L.M., Minato, H., Honda, M., Kaneko, S., Tang, Z.Y. \& Wang, X.W. 2009. EpCAM-positive hepatocellular carcinoma cells are tumor-initiating cells with stem/progenitor cell features. Gastroenterology, 136:10121024.

58. Yamashita, Y. \& Wang X.W. 2013. Cancer stem cells in the development of liver cancer. The Journal of Clinical Investigation, 123(5): 1911-18.

59. Yang, W, Yan, H.X., Chen, L., Liu, Q., He, Y.Q., Yu, L.X., Zhang, S.H., Huang, D.D., Tang, L., Kong, X.N., Chen, C., Liu, S.Q., Wu, M.C. \& Wang, H.Y. 2008. Wnt/beta-catenin signaling contributes to activation of normal and tumorigenic liver progenitor cells. Cancer Research, 68(11): 4287-4295.
60. Yang, W., Wang, C., Lin, Y, Liu, Q, Yu, L.X., Tang, L., Yan, H.X., Fu, J., Chen, Y., Zhang, H.L,. Tang, L., Zheng, L.Y., He, Y.Q., Li, Y.Q., Wu, F.Q., Zou, S.S., Li, Z., Wu, M.C., Feng, G.S. You, N., Zheng, L., Liu, W., Zhong, X., Wang, W. \& Li, J. 2014. Proliferation inhibition and differentiation induction of hepatic cancer stem cells by knockdown of BC047440: a potential therapeutic target of stem cell treatment for hepatocellular carcinoma. Oncology Reports, 31(4): 1911-1920.

61. Yin, C., Lin, Y., Zhang, X., Chen, Y.X., Zeng, X., Yue, H.Y., Hou, J.L., Deng, X., Zhang, J.P., Han, Z.G. \& Xie, W.F. 2008. Differentiation therapy of hepatocellular carcinoma in mice with recombinant adenovirus carrying hepatocyte nuclear factor-4alpha gene. Hepatology, 48(5): 1528-1539.

62. Yuan, F., Zhou, W., Zou, C., Zhang, Z., Hu, H., Dai, Z. \& Zhang, Y. 2010. Expression of Oct4 in HCC and modulation to wnt $/ \beta$-catenin and TGF- $\beta$ signal pathways. Molecular and Cellular Biochemistry, 343(1-2): 155-162.

63. Xiang, Y., Yang, T., Pang, B., Zhu, Y. \& Liu, Y. 2016. The Progress and Prospects of Putative Biomarkers for Liver Cancer Stem Cells in Hepatocellular Carcinoma. Stem Cells International, 2016: 1-15.

64. Xu, Z., Robitaille, A.M., Berndt, J.D., Davidson K.C., Fischer K.A., Mathieu J., Potter J.C., Ruohola-Baker H. \& Moon, R.T. 2016. Wnt/ $\beta$-catenin signaling promotes selfrenewal and inhibits the primed state transition in naïve human embryonic stem cells. Proceedings of the National Academy of Sciences of the United States of America, 18 (42): 113-121.

65. Zhan, T., Rindtorff, N. \& Boutros, M. 2017. Wnt signaling in cancer. Oncogene, 36: 1461-1473.

66. Zhang, S. Li, Y., Wu, Y., Shi, K., Bing, L. \& Hao, J. 2012. Wnt/b-Catenin Signaling Pathway Upregulates c-Myc Expression to Promote Cell Proliferation of P19 Teratocarcinoma Cells. The Anatomical Record, 295: 2104-2113.

67. Zheng, L., Liang, P., Li, J., Huang, X.B., Wang, W.W., Wang, L. \& Feng, H. 2010. Expression of BC047440 protein in hepatocellular carcinoma and its relationship to prognosis. Chinese Journal of Cancer, 29(11): 931-936.

68. Zhou, J.N., Zeng, Q., Wang, H.Y., Zhang, B., Li, S.T., Nan, X., Cao, N., Fu, C.J., Yan, X.L. \& Jia, Y.L. 2015. MicroRNA-125b attenuates epithelial-mesenchymal transitions and targets stem-like liver cancer cells through small mothers against decapentaplegic 2 and 4. Hepatology, 62: 801-815. 